\title{
TEKNOLOGI DIGITAL, KEBERLANJUTAN LINGKUNGAN, DAN DESA WISATA DI INDONESIA
}

\author{
Aan Jaelani, Tika Fatichah Hanim \\ Institut Agama Islam Negeri Syekh Nurjati Cirebon \\ Email: iainanjal@gmail.com dan tikafatichahhanim2018@gmail.com
}

\begin{abstract}
This article explores the importance of digital technology transformation in tourism villages and environmental sustainability in Indonesia amid village development that makes the economy, society, culture, and ecology potential villages promoted through tourism. The method used is a systematic, comprehensive microanalysis perspective used to analyze subsystems and the relationship between subsystems in a complex system in tourism management in the village. The development of tourist villages can be realized through technology, information, and communication that are applied in a complex and integrated manner with the five subsystems, namely strategic subsystems, social subsystems, economic subsystems, resource and environmental subsystems, and information subsystems. So that the transformation process into a digital tourism village can connect between components in tourism management, change business processes to be more optimal, efficient, and practical, improve tourism services quickly, and promote environmental sustainability in existing tourism objects.
\end{abstract}

Keywords:Smart Village, Digital Technology, Digital Tourism Village, Sustainability Environment

\begin{abstract}
Abstrak
Artikel ini bertujuan untuk mengeksplorasi pentingnya transformasi teknologi digital pada desa wisata dan keberlanjutan lingkungan di Indonesia di tengah pembangunan desa yang menjadikan ekonomi, masyarakat, budaya, dan ekologis sebagai potensi desa yang dapat dipromosikan melalui pariwisata. Metode yang digunakan berupa perspektif mikroanalisis komprehensif yang sistematis sebagai metode yang digunakan untuk menganalisis subsistem dan hubungan antar subsistem dalam sistem yang kompleks dalam pengelolaan pariwisata di desa. Pengembangan desa wisata dapat diwujudkan melalui teknologi, informasi, dan komunikasi yang diterapkan secara kompleks dan terintegrasi dengan kelima subsistem, yaitu subsistem strategis, subsistem sosial, subsistem ekonomi, subsistem sumber daya dan lingkungan, dan subsistem informasi. Sehingga proses transformasi menjadi desa wisata digital dapat menghubungkan antar komponen dalam pengelolaan pariwisata, mengubah proses bisnis semakin optimal, efisien, dan efektif, meningkatkan layanan pariwisata dengan cepat, dan mempromosikan kelestarian lingkungan pada obyek wisata yang ada.
\end{abstract}

Kata Kunci: Smart Village, Teknologi Digital, Desa Wisata Digital, Keberlanjutan Lingkungan 


\section{PENDAHULUAN}

Studi tentang teknologi digital dan keberlanjutan lingkungan pada desa wisata menjadi penting bagi pembangunan desa dan kesejahteraan masyarakat. Teknologi digital akan mempermudah wisatawan dalam mengunjungi desa secara langsung di destinasi wisata yang menjadi tujuan, bahkan bisa menikmati secara virtual tentang potensi dan keindahan desa. Begitu juga keberlanjutan lingkungan menjadi penting dalam pengelolaan pariwisata di desa sebagai tempat hidup masyarakat yang memiliki keaslian da keunikan. Hal ini sebagaimana ditemukan dalam beberapa hasil riset yang memperkenalkan bentukbentuk teknologi pariwisata, seperti panduan digital atau perangkat pencari jalan untuk mengembangkan potensi desa yang mengarah ke pariwisata dan keberlanjutannya (Laxmita et al., 2021), mempromosikan teknologi digital untuk mencegah eksklusi pedesaan, penggunaan desa pintar secara lebih intensif, dan penekanan pilar lingkungan sebagai bagian dari infrastruktur cerdas untuk memecahkan persoalan yang terjadi pada destinasi wisata (Vaishar \& Stastna, 2019),

Studi lain yang dikembangkan terkait dengan perkembangan teknologi dan digitalisasi termasuk pengembangan jaringan untuk desa pintar di Slovenia yang disebut dengan Jaringan Fab Lab sebagai lingkungan prototipe dan eksperimen Digital Innovation Hub Slovenia (DIHS) (Zavratnik et al., 2018), pembuatan media digital edukasi tentang desa adat di Indonesia yang menarik dan platform yang ramah pengguna terhadap teknologi internet dan ramah lingkungan (Nikmawati et al., 2019), membantu mereka dalam meregenerasi pariwisata dan warisan budaya, dari penggunaan teknologi digital dan media sosial, dan pembuatan prosedur internal untuk memperoleh sertifikasi kelestarian lingkungan (Romolini et al., 2017). Bahkan teknologi digital ini dikembangkan untuk optimalisasi konten promosi online, pengadaan sistem digital, perbaikan desa ramah lingkungan, peningkatan SDM, pengembangan kelembagaan yang berkualitas, perancangan paket wisata terintegrasi, pengadaan fasilitas teknologi sistem digital, dan peningkatan ramah lingkungan (Sugandi et al., 2020).

Perkembangan studi atas topik ini dikaitkan juga dengan pembangunan berkelanjutan di desa termasuk mempersiapkan konsep pariwisata berkelanjutan. Beberapa temuan riset menunjukkan bahwa geo-route pedesaan melintasi desa di pegunungan tinggi sebagai sarana untuk menjadikan geowisata sebagai wisata alam, mengutamakan pengalaman, sambil menjelaskan lingkungan alam dan pengembangan potensinya (Martínez-Graña et al., 2017), keberlanjutan lingkungan ditandai dengan pemanfaatan teknologi digital untuk mengubah penggunaan lahan dan memperkuat hubungan antara organisasi yang berbeda, memperkuat narasi tertentu dari lingkungan (Huggins, 2018), teknologi digital yang ditanamkan dalam lingkungan desa dapat membentuk ekosistem pariwisata cerdas berdasarkan infrastruktur teknologi yang ada.(Lee et al., 2020), dan pemanfaatan teknologi digital oleh pemerintah desa dengan melakukan optimalisasi peran masyarakat di desa wisata dalam menjaga lingkungan agar tetap nyaman dan aman untuk dikunjungi (Purnomo et al., 2020).

Pemanfatan teknologi digital dalam pariwisata menjadi kebutuhan utama bagi para pengelola pariwisata terutama di desa dengan keragaman dan keunikan potensi yang dimilikinya. Keterbatasan akses internet bagi desa, sarana dan prasarana yang tidak menunjang bagi pengunjung, kelemahan sumber daya manusia dalam menggunakan teknologi digital dan mengelola destinasi pariwisata, dan kesadaran lingkungan menjadi bagian dalam pengembangan pariwisata di desa. Dalam membangun desa pariwisata, masyarakat kurang memperhatikan aspek 
lingkungan sosial ekonomi dan memanfaatkan teknologi digital dalam aktivitasnya seiring dengan perkembangan revolusi industri 4.0 (Pradana \& Arcana, 2020), penggunaan perangkat informasi digital seperti ponsel, televisi berwarna, televisi digital, dan lainnya oleh penduduk pedesaan juga tidak dapat dimanfaatkan untuk kelestarian subsistem lingkungan dari lapisan fisik (Zhang \& Zhang, 2020).

Teknologi digital secara sistematis dapat merekam pengetahuan dan keterampilan teknis budaya, termasuk melakukan konservasi warisan desa kuno, pembangunan pariwisata ekologi masyarakat; perlindungan kesehatan masyarakat wisatawan, dan perlindungan lingkungan (Katsoni \& Spyriadis, 2020), memberikan dorongan yang kuat untuk inovasi pariwisata, pengembangan ekowisata, wisata pedesaan dan desa, serta jalur religi yang dapat meningkatkan inklusivitas sosial, pengurangan kemiskinan, dan lingkungan (Notarstefano \& Gristina, 2021). Bahkan, teknologi digital dapat menjadikan desa pintar untuk meningkatkan desa-desa kecil dengan fokus pada kelestarian lingkungan dengan tujuan pariwisata hijau dan lambat (Calomino, 2020).

Secara sosial, masyarakat pada desa wisata yang telah menggunakan teknologi digital dapat melakukan pemasaran produk untuk proses branding daerah lokal bagi pengunjung wisata, sekaligus mempromosikan urgensi kepedulian terhadap pariwisata dan lingkungan, karena lingkungan akan terganggu oleh kegiatan pariwisata (Sitorus, 2020), dan menguatkan pariwisata berkelanjutan dengan tiga pilar mencakup lingkungan, sosial, dan hukum yang terkoneksi dengan digital dan pengalaman (Della Corte et al., 2019). Beberapa kendala biasanya muncul seiring dengan era disrupsi yang ditandai dengan perkembangan teknologi, globalisasi, dan inovasi digital berupa ketidakmampuan dalam mentransformasikan desa menjadi desa wisata yang cerdas yang dikembangkan dari desa pintar dan pariwisata berkelanjutan (Rudwiarti et al., 2021).

Pemanfaatan teknologi tidak difokuskan pada pengembangan ekowisata yang menerapkan desa wisata cerdas dan pembangunan pariwisata yang memperhatikan ekonomi saat ini dan masa depan yang memenuhi kebutuhan pengunjung, industri, sosial dan lingkungan (Sary et al., 2021). Di sinilah pentingnya pengembangan sumber daya dan kemampuan yang dibutuhkan untuk proses transformasi digital dan mengevaluasi pengaruh teknologi digital terhadap aktivitas pariwisata yang melibatkan seluruh komponen seperti komponen masyarakat, UKM, manufaktur, pengelola pariwisata, pemerintahan desa, dan lainnya (Gomez-Trujillo \& Gonzalez-Perez, 2021).

Di Indonesia, desa wisata mulai mamanfaatkan teknologi digital dalam pengelolaannya. Pada tahun 2021, seperti dinyatakan Ketua Umum Asosiasi Desa Wisata Indonesia (Asidewi), Andi Yuwono, Indonesia memiliki 1.838 desa wisata sesuai dengan data dari Kemenparekraf (Kementerian Pariwisata dan Ekonomi Kreatif) (Ramadian, 2021). Kemenparekraf sendiri menyelenggarakan lomba Anugerah Desa Wisata Indonesia 2021 untuk kategori desa rintisan, berkembang, maju, dan mandiri dengan tujuh kategori, yaitu CHSE, desa digital, souvenir (kuliner, fesyen, kriya), daya tarik wisata (alam, budaya, buatan), konten kreatif, homestay, dan toilet.

Desa wisata rintisan sebagai desa yang memiliki potensi dan obyek wisata, tapi belum memiliki produk. Desa wisata yang berkembang sudah bisa menerima wisatawan, seperti Desa Wisata Cibuntu di Kabupaten Kuningan. Adapun desa wisata mandiri telah memiliki produk wisata dan sebagai desa percontohan, seperti Desa Wisata Candirejo di Kabupaten Magelang, Jawa Tengah, Desa Wisata Pentingsari di 
Kabupaten Sleman, Yogyakarta, dan Desa Wisata Tamansari di Kabupaten Banyuwangi, Jawa Timur.

Artikel ini bertujuan untuk mengeksplorasi pemanfaatan teknologi digital pada desa wisata dan keberlanjutan lingkungan di Indonesia. Hal ini terkait dengan tujuan pembangunan berkelanjutan di desa yang mempromosikan teknologi digital dalam mewujudkan desa pariwisata dan keberlanjutan lingkungan di tengah pembangunan desa yang menjadikan ekonomi, masyarakat, budaya, dan ekologis sebagai bagian yang menyeluruh untuk dikembangkan melalui promosi desa wisata. Meskipun pemanfaatan teknologi digital bukan satu-satunya yang penting dalam menjadikan suatu desa mandiri (Zavratnik et al., 2018), namun riset lain menunjukkan bahwa penerapan teknologi digital dapat memfasilitasi pembangunan berkelanjutan di pedesaan (Adamowicz \& ZwolińskaLigaj, 2020) dan mempromosikan pembangunan desa pintar berdasarkan subsistem strategis pada desa pintar sesuai kebutuhan daerah (Zhang \& Zhang, 2020).

\section{LITERATURE REVIEW}

Beberapa studi tentang teknologi digital, keberlanjutan lingkungan, dan desa wisata dapat diklasifikasikan pada 3 fokus pembahasan, yaitu: 1) teknologi digital, pembangunan, dan pariwisata desa, 2) smart desa, desa pariwisata, dan lingkungan, dan 3) teknologi digital, keberlanjutan pariwisata, dan keberlanjutan lingkungan desa.

Kategori pertama, teknologi digital, pembangunan, dan pariwisata desa termasuk pengembangan potensi dan sumber daya desa dan masyarakat lokal. Beberapa hasil riset pada kategori ini memfokuskan pada pengembangan teknologi digital dalam pembangunan dan pariwisata pedesaan oleh masyarakat pedesaan (Rochman et al., 2020), merevitalisasi sumber daya pedesaan untuk manfaat sosial ekonomi lokal dan kelestarian lingkungan melalui pemberdayaan masyarakat lokal (Istanti, 2021), dan pengembangan jaringan dan layanan masyarakat melalui teknologi digital, telekomunikasi, inovasi, dan pemanfaatannya untuk membantu meningkatkan kualitas hidup (Brahi \& Bensaid, 2019).

Secara khusus, kajian teknologi digital, pembangunan, dan pariwisata desa di Indonesia memfokuskan pada fungsi teknologi digital sebagai katalis untuk pembangunan penggunaan internet dan (Fauziah \& Nasdian, 2021), untuk mewujudkan kawasan wisata halal dengan memanfaatkan potensi pariwisata unggul sebagai program pembangunan (Rachmadi, 2020), pengembangan kapasitas petani dalam pembangunan pariwisata (Subejo et al., 2021),

penerapan teknologi digitalisasi pariwisata berbasis masyarakat pada desa wisata (Kurniawan, 2020), dan pelatihan media online untuk meningkatkan literasi informasi kalangan milineal pada program pembangunan desa dalam mewujudkan desa wisata (Nugraha et al., 2019), dan keberhasilan dan keberlanjutan destinasi wisata masyarakat mempertimbangkan aspek ekonomi, sosial, budaya, dan lingkungan dengan memperkuat kelembagaan, partisipasi masyarakat, dan pengembangan promosi berbasis teknologi digital (Soeswoyo, 2021).

Kategori kedua, smart desa, desa pariwisata, dan lingkungan termasuk inovasi teknologi digital dalam mengembangkan desa cerdas untuk pariwisata dan lingkungan. Pada ketegori ini, inovasi teknologi digital seperti augmented reality dan virtual reality, hologram, dan digital twins yang digunakan untuk membuat situs budaya menarik bagi semua jenis turis yang direproduksi ke lingkungan yang sesuai (Frey \& Briviba, 2021), penggunaan alat-alat digital yang 
dipromosikan untuk lokal dan pengunjung dengan memanfaatkan lingkungan dan menghasilkan pengalaman dengan menggunakan teknologi berbasis geo secara optimal untuk memungkinkan wisatawan mengintegrasikan multimedia dan geospasial pada desa pariwisata (Ricart et al., 2019), dan pembangunan pariwisata berkelanjutan dan pemasarannya melalui teknologi Web 3.0 yang diterapkan untuk semua jenis pariwisata dan lingkungan (Liu \& Mačerinskienè, 2016).

Kajian smart desa, desa pariwisata, dan lingkungan lebih menekankan pada kemampuan untuk beradaptasi dan menguasai

perkembangan teknologi digital untuk merancang platform digital untuk pariwisata (Puspawati \& Ristanto, 2018), merancang peta digital untuk media promosi dan informasi desa pariiwsata (Kahfi \& Sarjan 2020), smart village yang mampu memberikan informasi yang lengkap melalui teknologi digital tentang potensi dan keunikan desa, serta menciptakan bangunanbangunan atau gedung yang ramah lingkungan (green and intelegent building) (Subekti \& Damayanti, 2019), smart kampung dirancang untuk pemberdayaan ekonomi melalui aspek pengembangan pariwisata, homestay, dan homeindustry (Maulidia, 2019), pariwisata pintar di desa wisata untuk meningkatkan aspek lingkungan, ekonomi dan sosial (Yasmine et al., 2021), smart desa dirancang untuk pengembangan agrowisata menjadi objek wisata yang berwawasan lingkungan dan memperhatikan keunikan lingkungan (Handayani \& Rahmi 2018), pengembangan smart village melalui pembuatan basis data desa, partisipasi aktif dari masyarakat, dan pemanfaatan potensi sumberdaya wilayah dan lingkungannya (Rachmawati, 2018), smart village untuk membangun dan lingkungan perdesaan dengan desa wisata (Saputra \& Isnain, 2021), smart village mengadopsi komponen dan indikator pada smart city berupa tiga kategori kondisi lingkungan, yakni kondisi geografis dan kondisi iklim (cuaca) dan kategori angin (Raldianingrat \& Fitria 2021), dan pemetaan kawasan dalam bentuk model yang terukur yang mempermudah proses pencitraan kawasan desa wisata dan mempermudah dalam proses desain (Dewi, 2020).

Kategori ketiga, teknologi digital, keberlanjutan pariwisata, dan keberlanjutan lingkungan desa termasuk kelestarian dan konservasi lingkungan alam di desa termasuk produk pariwisata digital dan pemasarannya. Klasifikasi ini memfokuskan pada pariwisata berkelanjutan yang berbasis inovasi digital dan tidak mengeksploitasi ekonomi, sosial, budaya, dan lingkungan, peningkatan kerjasama dan kolaborasi dalam membangun desa pariwisata, dan pengembangan destinasi wisata yang berkelanjutan dengan mengembangkan potensi sosial, ekonomi, dan teknologi (Yasir et al., 2021), pengembangan solusi digital masa depan yang menekankan aspek manusia dan lingkungan dengan mendekatkan kota pintar pada keberlanjutan perkotaan dan pedesaan (Zavratnik et al., 2020), peningkatan dalam penggunaan pengetahuan digital dengan berbagai platform teknologi untuk berbagi pengetahuan budaya di bidang pariwisata, memberdayakan komunitas adat lokal yang terlibat dalam pariwisata, dan mendidik penduduk lokal dan wisatawan untuk keberlanjutan lingkungan (McGinnis et al., 2020), serta mengoptimalkan tiga unsur utama untuk keberlanjutan pariwisata seperti aspek lingkungan, sosial (masyarakat), dan hukum dengan memberikan kemudahan akses bagi kunjungan wisatawan (Namono, 2018).

Sementara itu, kajian teknologi digital, keberlanjutan pariwisata, dan keberlanjutan lingkungan lebih memfokuskan pada pembangunan pariwisata yang 
berkelanjutan dan berwawasan lingkungan dilakukan dengan program desa binaan dalam pembangunan dan pengembangan desa tersebut dengan payung green tourism (Suprapto, 2021), peningkatan promosi wisata dan sistem informasi berbasis digital di desa untuk keberlanjutan ekonomi, kesejahteraan masyarakat, keadilan sosial, ketenagakerjaan, dan kendali masyarakat pada aktivitas pariwisata (Budiani et al., 2018; Jaelani, 2013), potensi dan keunikan desa dimanfaatkan untuk atraksi pariwisata dengan menjaga keberlanjutan lingkungan melalui sistem sosial yang dibangun melalui teknologi digital (Aji, 2021), teknologi digital menciptakan peluang bagi pelaku UMKM sehingga pengelola pariwisata desa bisa mengeksplorasi dan memberdayagunakan potensi desa (As'adi et al., 2020), pemanfaatan teknologi digital untuk pembangunan pariwisata berkelanjutan dengan mentransformasi media ke arah digital pada wisata desa (Rachmat, 2021), pembangunan pariwisata berkelanjutan

berbasis teknologi digital pada desa wisata yang berfokus pada penerapan standar berkelanjutan, yaitu sosial, lingkungan, dan

(Nadra, 2021), perancangan desa wisata memerhatikan aspek pembangunan desa yang mementingkan kesejahteraan masyarakat dan keberlanjutan lingkungan (Rumiati et al., 2021; Jaelani \& Hanim, 2020; Jaelani et al., 2020), penerapan teknologi informasi untuk pembangunan green toruism pada wisata pedesaan yang memerhatikan keunikan alam dan lingkungan untuk keberlanjutan ekonomi dan pembangunan (Adnyana, 2020; Jaelani et al., 2017), dan pengembangan wisata bahari melalui pendekatan potensi desa dengan pemanfaatan jasa sumber daya kelautan dan perikanan sebagai daya tarik wisata untuk membangun desa wisata sesuai tujuan keberlanjutan (Hidayati \& Nugrahani 2021).

Dari studi literatur di atas, artikel ini lebih memfokuskan pada penggunaan teknologi digital dalam pembangunan berkelanjutan di desa melalui desa wisata dan lingkungan sebagai suatu sistem dan subsistem yang kompleks dengan menggunakan analisis pada perspektif analisis mikro komprehensif yang sistematis. Analisis ini untuk memetakan pembangunan berkelanjutan pada desa wisata dan lingkungan sekitarnya sebagai sistem yang komprehensif dikembangkan melalui pemanfaatan teknologi digital.

\section{METODE PENELITIAN}

Tulisan ini menggunakan metode yang menerapkan perspektif mikroanalisis komprehensif yang sistematis (a systematic comprehensive microanalysis perspective). Metode analisis ini adalah metode ilmiah yang digunakan untuk menganalisis subsistem dan hubungan antar subsistem dalam sistem yang kompleks. Ini menggambarkan sistem multibody yang lengkap dengan kombinasi yang jelas dari individu makroskopik dan banyak individu mikroskopis yang diposisikan dengan jelas (Auyang, 1998).

Untuk lebih menggambarkan sistem desa pintar seperti yang dilakukan oleh (Zhang \& Zhang, 2020), artikel ini menggambarkan keadaan mikro dari sistem desa pintar dengan subsistem strategis, subsistem sosial, subsistem ekonomi, subsistem sumber daya dan lingkungan, dan subsistem informasi yang diterapkan pada desa wisata digital. Kemudian hierarki struktural sistem desa pintar diilustrasikan dengan kompleksitas lapisan fisik, lapisan aktivitas, dan lapisan strategis yang rendah hingga tinggi. Bangunan model sistem desa pintar seperti pada Gambar 1 berikut untuk menjelaskan desa wisata digital yang dikembangkan di Indonesia. 


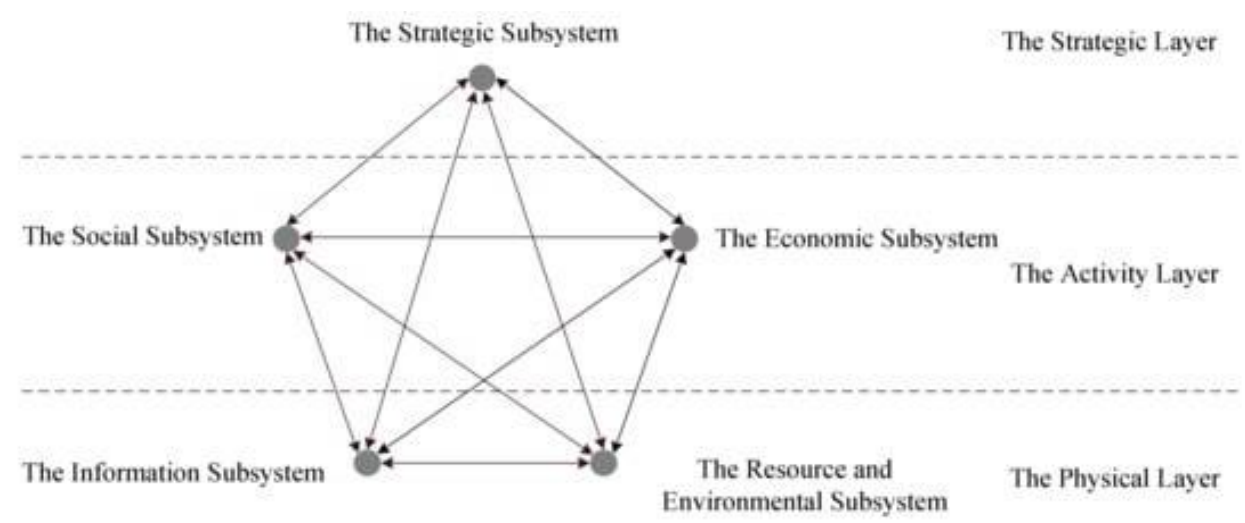

Gambar 1. Sistem Desa Pintar (Smart Village Systems) untuk Desa Wisata Digital Sumber: Zhang \& Zhang (2020)

Untuk lebih jelas, penulis melakukan langkah-langkah berikut ini: pertama, menemukan masalah tentang pemanfaatan teknologi digital pada pembangunan desa di bidang pariwisata dan keberlanjutan lingkungan; kedua, mengumpulkan data sekunder tentang praktik desa pintar, perkembangan desa wisata, dan pembangunan lingkungan berkelanjutan secara menyeluruh yang diperoleh dari publikasi ilmiah dan informasi dari kementerian dan lembaga terkait, seperti Kemenparkraf dan desa wisata digital; ketiga, menyusun jawaban dengan mengklasifikasi dan memilah data yang relevan dengan pengelolaan teknologi digital pada desa wisata dan dampak pada lingkungan; keempat, menganalisis data dengan perspektif analisis mikro komprehensif yang sistematis (Zhang \& Zhang, 2020) yang menafsirkan bagianbagian utama sistem dan subsistem yang kompleks dalam menjelaskan desa wisata, dan kelima, membuat kesimpulan artikel ini.

\section{KONSEP DASAR}

\section{Konsep dan Struktur Smart Village}

Istilah "desa pintar" digunakan sebagai cara penting untuk mencapai keberlanjutan pedesaan yang mengadopsi teori "kota pintar" dan "pembangunan dari bawah ke atas". Konsep "kota pintar" berorientasi pada penghematan sumber daya, perencanaan tata ruang yang tepat, manajemen transportasi, pengurangan biaya akibat urban sprawl, dan penggunaan inovasi yang luas terutama terkait dengan teknologi dan digitalisasi. Penggunaan teknologi informasi dan digital untuk menciptakan interaktivitas dan efisiensi permukiman perkotaan, investasi baru dalam modal manusia dan sosial, infrastruktur komunikasi, penggunaan sumber daya yang efisien, serta perluasan partisipasi warga dalam program pembangunan diperlukan (Adamowicz \& Zwolińska-Ligaj, 2020; Mohanty et al., 2020).

Sedangkan gagasan pengembangan sistem lokal dari bawah ke atas di daerah pedesaan dapat menciptakan kecerdasan desa dengan penggunaan aset spesifik lokal secara ekstensif, termasuk pengetahuan tacit masyarakat yang terkena dampak tekanan pembangunan (Jaelani et al., 2020). Elemen-elemen model kota pintar seperti lingkungan, manusia, kualitas hidup, manajemen, mobilitas, ekonomi, penelitian dan inovasi, dengan cepat telah dipindahkan ke bidang pembangunan daerah, dan barubaru ini, juga ke program pembangunan berkelanjutan pedesaan. Program Smart Village Uni Eropa bertujuan menjembatani dua konsep asli ini (European Commission, 2018].

Konsep desa pintar mengacu pada daerah pedesaan dan masyarakat pedesaan yang telah membangun strategi 
pembangunan mereka di atas aset dan kekuatan mereka yang ada, serta dengan mengejar beberapa peluang baru terkait dengan teknologi digital, jaringan, dan layanan baru yang mendukung penggunaan pengetahuan dan solusi inovatif yang lebih baik untuk warga negara, bisnis dan masyarakat. Desa pintar "menggunakan solusi inovatif untuk meningkatkan ketahanan mereka, membangun kekuatan dan peluang lokal." (Directorate-General for Agriculture and Rural Development, European Commission, 2019; Patnaik et al., 2020).

Dalam pengembangan konsep cerdas pada pembangunan infrastruktur di pedesaan (smart villages) dan perkotaan (smart city) dilakukan pada kedua ruang secara bersamaan (Srivatsa, 2015). Kedua istilah ini tidak memiliki definisi yang jelas dan pasti karena bergantung pada lingkungan dan perubahan dalam struktur sosial budaya (Gascó-Hernandez, 2018). Namun, Edwards dan Haines (2007) memberikan kriteria berikut: (1) menciptakan pilihan dan peluang perumahan baru; (2) membuat masyarakat lebih mudah diakses dengan berjalan kaki; (3) membangun tempat yang nyaman dalam masyarakat; (4) melestarikan zona lingkungan yang berbeda; (5) menghubungkan tujuan-tujuan pembangunan yang baru dan yang sudah ada; dan (6) lebih banyak variasi dalam hal transportasi. Pada perkembangan di Uni Eropa, konsep cerdas ini merujuk pada pertumbuhan "ekonomi berbasis pengetahuan" (Naldi et al., 2015).

Dimensi cerdas dari pembangunan tidak terfokus pada label "pintar" tetapi juga dapat terjalin dengan dimensi lain, seperti dalam kasus SDGs dengan dimensi cerdas yang ditangani oleh masyarakat pedesaan pada aspek-aspek spesifik lainnya: keberlanjutan, kesejahteraan, pendidikan (kualitas inklusif dan keadilan), pemberdayaan perempuan dan anak perempuan, pengelolaan sumber daya air, aksesibilitas energi berkelanjutan, pertumbuhan ekonomi berkelanjutan dan pekerjaan yang layak, membangun infrastruktur yang tangguh, mendorong inovasi, mengurangi ketidaksetaraan, membuat pemukiman manusia lebih inklusif dan berkelanjutan, mengambil tindakan untuk memerangi perubahan iklim, melindungi ekosistem, dll. (Glasmeier \& Christopherson, 2015). Dengan demikian, konsep cerdas ini selalu bergantung pada kasus dan berdasarkan kondisi tertentu, misalnya, lokalitas, kondisi geografis, sumber daya sosial dan alam yang ada, serta dipengaruhi oleh tantangan paling nyata yang dihadapi masyarakat lokal (Hayat, 2016).

Adapun struktur dasar pada desa pintar berdasarkan kerangka teori sistem desa pintar dapat diilustrasikan pada Gambar 2 yang mengadopsi gagasan dari Zhang \& Zhang (2020) pada desa cerdas dengan ilustrasi pada pertanian cerdas. Penulis kemudian mengilustrasikan pada pengembangan pariwisata cerdas. Pada tahap awal, menentukan tipe desa pintar yang dibutuhkan masyarakat berdasarkan karakteristik, kelebihan dan kekurangannya. Pada tingkat strategis, kami mencantumkan beberapa tipe desa cerdas yang khas, termasuk "desa pertanian cerdas", "desa layanan publik cerdas", "desa e-commerce", "desa wisata cerdas", "desa cerdas tipe pembangunan komprehensif", dan termasuk "desa wisata digital". Misalnya, jika sebuah desa lebih maju di bidang pariwisata dapat dikembangkan menjadi desa wisata yang cerdas. Pada tingkat aktivitas difokuskan pada pengembangan "pariwisata pintar" di subsistem pariwisata dan bagian terkait produk parawisata pada e-commerce pedesaan dan logistik pintar pedesaan. Subsistem informasi dari lapisan fisik berfokus pada pembangunan platform cloud pariwisata.

Sementara sumber daya lapisan fisik dan subsistem lingkungan berfokus pada pembangunan sistem pengelolaan pariwisata 
yang cerdas, sistem pemantauan keterlacakan elektronik untuk input kunjungan wisatawan, dan sistem efektivitas yang menghubungkan tempat-tempat pariwisata dan lingkungan yang cerdas. Tentu saja, beberapa infrastruktur informasi dan terminal informasi dari subsistem informasi di lapisan fisik adalah opsi wajib, terlepas dari jenis desa pintar apa yang dibangun. Oleh karena itu, untuk pembangunan desa wisata pintar di desa yang berbeda, desain tingkat atas khusus untuk desa yang berbeda harus dilakukan mengikuti standar nasional terpadu untuk memastikan bahwa pembangunan desa pintar benar-benar dapat membantu desa memecahkan masalah dan mewujudkan pembangunan berkelanjutan, termasuk dalam pariwisata dan lingkungan (Zhang \& Zhang, 2020).

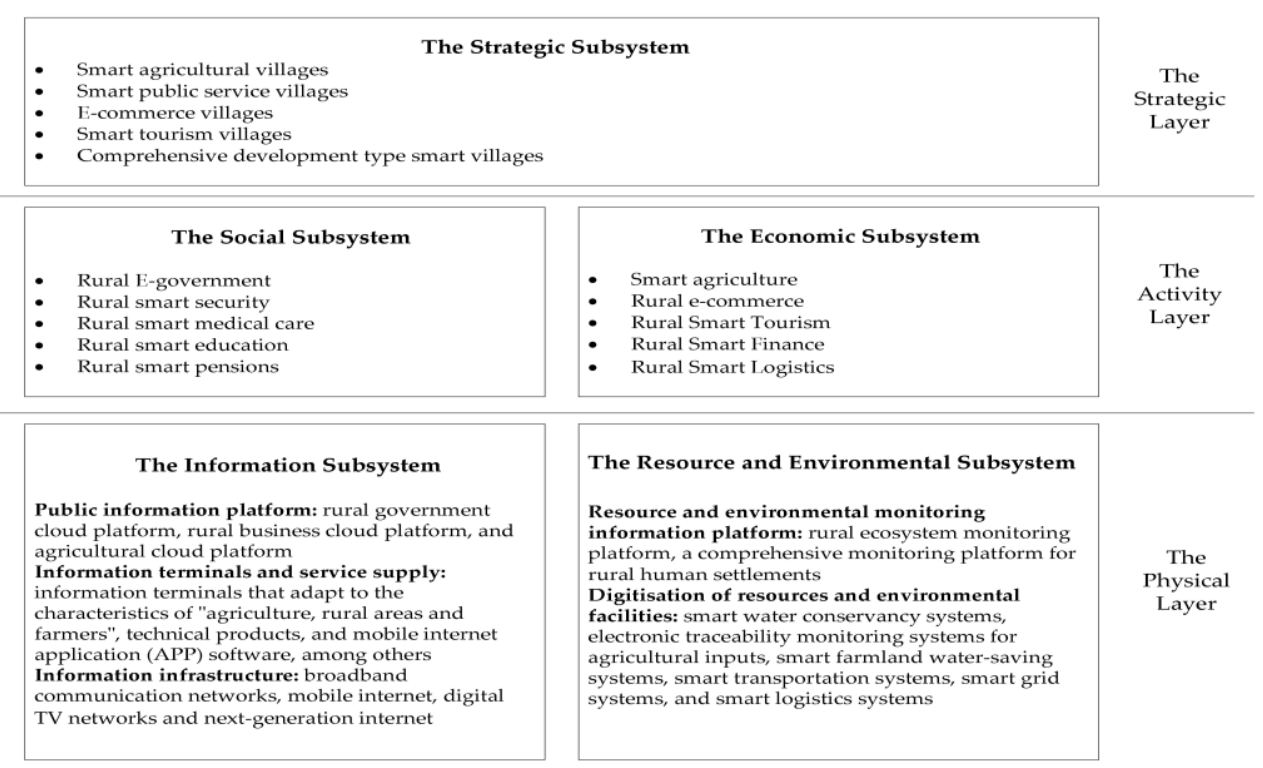

Gambar 2. Struktur Dasar Smart Village

Sumber: Zhang \& Zhang (2020)

Teknologi Digital dan Pembangunan Lingkungan Berkelanjutan pada Desa Wisata

Pengembangan teknologi digital pada desa digital untuk meningkatkan ekonomi lokal dengan pembangunan infrastruktur secara berkelanjutan. Pembangunan desa digital harus memerhatikan faktor lingkungan pedesaan dan kondisi lokal yang berbeda (Gao et al., 2021). Stojanova et al. (2021) menegaskan bahwa teknologi digital dapat dimanfaatkan untuk menjembatani kesenjangan desa-kota dan memobilisasi solusi yang ditawarkan dengan rposes transformasi yang memerhatikan kondisi ekonomi, sosial, dan/atau lingkungan mereka. Kesenjangan digital tersebut semakin berkurang dengan teknologi dasar, seperti koneksi ke saluran Asymmetric Digital Subscriber Line (ADSL) (Pérez-delHoyo \& Mora, 2019)

Bahkan, operator budaya harus memanfaatkan peran penggerak inovasi teknologi digital pada pariwisata dengan memfokuskan pada empat bidang utama, yaitu pemasaran, operasi, lingkungan, dan pembangunan berkelanjutan, dan teknologi baru (Sigala \& Leslie (2006). Namun demikian, hubungan teknologi antara warisan dan ekonomi pariwisata berkelanjutan dibangun berdasarkan kekayaan budaya masyarakat untuk menciptakan lingkungan bisnis baru (Njovo \& Makacha, 2018), promosi peningkatan kunjungan wisatawan era digital (Geria et al., 2018), dan menggambarkan perilaku 
lingkungan yang berkelanjutan, khususnya di bidang pariwisata (Cohen et al., 2014).

Lanskap pedesaan menyatukan kelestarian lingkungan dengan kegiatan pariwisata yang memanfaatkan teknologi digital untuk pengembangan tata kelola pariwisata berkelanjutan di pedesaan (Garau, 2015), sehingga knowledge sharing pada teknologi dan transformasi digital perlu dimanfaatkan secara optimal Sapta et al., 2020). Sebagaimana ditegaskan Gorain (2022) bahwa kerangka kerja berkelanjutan untuk desa pintar yang memanfaatkan digital dan teknologi untuk mencapai tujuan utama dalam meningkatkan kehidupan manusia dan lingkungan dari sisi tata kelola, literasi digital, dan peningkatan berkelanjutan melalui adopsi teknologi baru. Kumar \& Sikarwar (2017) mendeskripsikan pentingnya menciptakan iklim investasi yang lebih baik dan lingkungan yang berkelanjutan melalui pemanfaatan teknologi elektronik-digital dan teknologi komputasi cerdas untuk meningkatkan desa menjadi desa pintar. Gomez-Oliva et al. (2019) menyarankan adanya siklus konten yang berkelanjutan melalui kerjasama pengunjung digital dan penggunaan saluran inovatif teknologi, yang diuji di lingkungan dunia nyata, untuk menyelamatkan esensi desa sebagai pilar utama merek wisatanya, sehingga dapat dimanfaatkan untuk mencapai pembangunan desa yang berkelanjutan (Lin, 2021), pengembangan pariwisata masyarakat (Tongdhamachart, 2017), dan penerapan program-program digital seperti layanan digital, transportasi digital, dan pendidikan berbasis teknologi kelestarian lingkungan dan ekonomi (Sulistyaningsih et al., 2021). Jadi, smart desa yang selaras dengan teknologi Industri 4.0 untuk pencapaian Tujuan Pembangunan Berkelanjutan (SDGs) dengan menciptakan lingkungan yang aman dan berkelanjutan (Maja et al., 2020).

\section{Strategi Pengembangan Desa Wisata Digital di Indonesia}

Desa adalah fondasi ekonomi bangsa (UU RI No. 6 Tahun 2016) sebagai kekuatan ekonomi agar warganya tak hijrah ke kota. Sepinya desa adalah modal utama untuk bekerja dan mengembangkan diri. Desa bisa memanfaatkan potensi pariwisata. Desa ini bagian dari pengembangan pariwisata berkelanjutan dan menjadi salah satu program pemerintah yang dapat mempercepat kebangkitan pariwisata dan memicu pertumbuhan ekonomi. Konsep wisatanya lebih bersahabat dengan alam dan masyarakat lokal sebagai pariwisata alternatif yang mampu menarik wisatawan untuk datang ke desa-desa (Al Banjari 2021; Wirdayanti, 2021).

Transformasi dan digitalisasi harus mengarah kepada budaya digital dengan pembuatan model perangkat bisnis dan alur kerja melalui pemanfaatan teknologi. Perubahan sosial budaya merupakan perubahan pola perilaku dan unsur-unsur sosial budaya yang mempengaruhi perubahan sistem dan struktur sosial, disebabkan oleh berbagai kondisi termasuk perkembangan teknologi informasi.

Untuk memahami desa wisata, penulis menyajikan perbedaan antara wisata desa dan desa wisata. Wisata desa mencakup: 1) kegiatan wisata yang berlangsung di desa; 2) tujuan perjalanan tidak selalu berbasis pada sumber daya wisata bersifat perdesaan sepanjang berlokasi di desa; 3) pelaku perjalanan wisata dapat menginap atau tidak menginap; 4) kegiatan wisata yang mengambil pilihan lokasi desa, dan jenis kegiatannya tidak harus berbasis pada sumber daya perdesaan (keaslian benteng alam, budaya, dan kearifan lokal); 5) objek wisata yang kebetulan telah ada di suatu desa seperti wisata alam, wisata buatan, wisata sejarah, dll.; 6) keterlibatan masyarakat terbatas dan dibatasi, hanya beberapa orang tertentu saja yang terlibat (Al Banjari 2021; Wirdayanti, 2021; Jaelani, 2021). 
Adapun desa wisata meliputi: 1) kawasan yang memiliki potensi dan keunikan daya tarik wisata yang khas, yaitu merasakan pengalaman keunikan kehidupan dan tradisi masyarakat di pedesaan dengan segala potensinya; 2) kelompok masyarakat yang berusaha di bidang pariwisata yang mencakup atraksi, akomodasi dan fasilitas pendukung di dalam wilayah desa/kelurahan dengan prinsip pariwisata berbasis masyarakat; 3) wilayah administratif desa yang memiliki potensi dan keunikan daya tarik wisata yang khas, yaitu merasakan pengalaman keunikan kehidupan dan tradisi masyarakat di perdesaan dengan segala potensinya; 4) suatu daerah tujuan wisata atau destinasi pariwisata, yang mengintegrasikan daya tarik wisata, fasilitas umum, fasilitas pariwisata, aksesibilitas, yang disajikan dalam suatu struktur kehidupan masyarakat yang menyatu dengan tata cara dan tradisi yang berlaku (UU RI Nomor 10 Tahun 2009 tentang Kepariwisataan) (Wirdayanti, 2021).

Desa wisata biasanya menunjukkan tema produk pariwisata yang diutamakannya. Tema ini serupa dengan tema desa industri, desa kerajinan, desa kreatif, desa budaya, dll. Jenis desa ini menyangkut semua komponen yang ada maupun dimiliki suatu desa yang bisa dikemas, disajikan, dan dijual untuk menjadi satu paket wisata. Obyek yang dieksplorasi adalah kultur budaya yang ada di masyarakat seperti objek wisata alam, wisata budaya, wisata sejarah, wisata kuliner, maupun wisata buatan. Semua unsur desa dari kepala desa, perangkat desa, struktural RT dan warga masyarakat setempat memiliki keterlibatan di dalamnya. Karena itu, lembaga harus bisa meningkatkan partisipasi masyarakat dalam pembiayaan desa wisata. Masyarakat dilibatkan secara komprehensif, diberi kewenangan, dan tugas sesuai dengan potensi yang ada di desanya. Kegiatan wisata yang dilakukan pada obyek wisata desa, atau obyek dan wisata desa adalah kegiatannya. Keduanya adalah potensi besar yang dimiliki berbagai desa di Indonesia yang saat ini sedang semarak berkembang menjadi potensi peningkatan ekonomi pedesaan (Wirdayanti, 2021)).

Adapun prinsip-prinsip pengembangan desa wisata dapat dilihat pada Gambar 3 berikut ini:

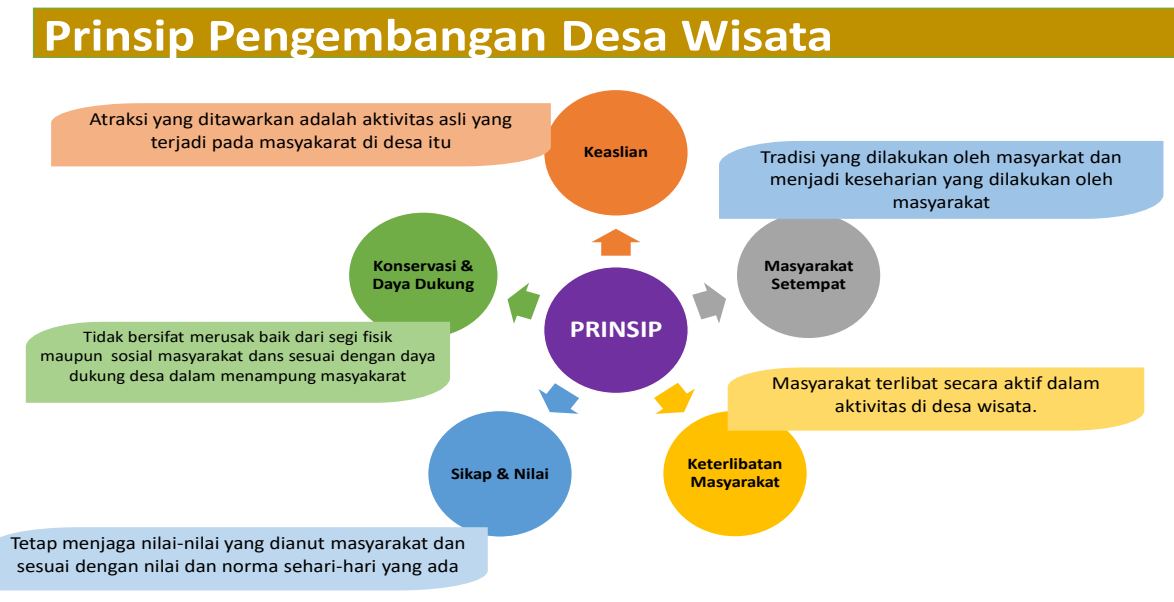

Gambar 3. Prinsip Pengembangan Desa Wisata

Desa wisata di Indonesia dapat dikelompokkan menjadi 4 jenis, yaitu: 1) desa wisata berbasis keunikan sumber daya alam. Desa ini menjadikan kondisi alam sebagai daya tarik utama seperti pegunungan, lembah, pantai, sungai, dan 
danau berbagai bentuk benteng alam yang unik; 2) desa wisata berbasis keunikan sumber daya budaya lokal. Desa ini menjadikan keunikan adat tradisi dan kehidupan keseharian masyarakat menjadi daya tarik utama, seperti aktivitas mata pencaharian, religi, budaya, dll.; 3) desa wisata kreatif. Desa ini menjadikan keunikan aktivitas ekonomi kreatif dan kegiatan industri rumah tangga masyarakat lokal, berupa kerajinan dan aktivitas kesenian yang khas menjadi daya tarik utama; dan 4) desa wisata berbasis kombinasi. Desa ini mengkombinasikan antara satu atau lebih daya tarik wisata yang dimiliki seperti alam, budaya, dan kreatifitas (Al Banjari 2021; Wirdayanti, 2021)..

Pemanfaatan teknologi digital pada desa sangat penting untuk pembangunan dan keberlanjutan pariwisata sehingga bertransformasi menjadi desa wisata digital. Desa digital merupakan desa yang memanfaatan Teknologi Informasi dan Komunikasi (TIK) dalam semua aspek pembangunan desanya dengan tujuan untuk peningkatan kualitas pelayanan publik yang efisien, peningkatan daya saing desa dengan inovasi desa dan penyelesaian masalahmasalah desa yang strategis (Jaelani, et al., 2020; Wirdayanti, 2021). Dengan TIK masyarakat desa dapat mewujudkan peningkatkan standar hidupnya yang dibarengi dengan peningkatan literasi digital sehingga masyarakat memiliki kemampuan memanfaatkan TIK, seperti pemanfaatan internet untuk peningkatan aspek pengelolaan lingkungan, ekonomi pendidikan, peluang inovasi, stabilitas sosial dan lain-lainnya. Pemanfaatan TIK ini yang menjadikan perubahan desa wisata menjadi desa wisata digital.

Pembangunan desa wisata digital dapat dilakukan dengan penerapan strategi revitalisasi pedesaan dan pembangunan desa pintar sebagai metode dan pendekatan untuk mencapai revitalisasi pedesaan dan pembangunan berkelanjutan (Zhang \& Zhang, 2020). Berdasarkan kerangka teori sistem desa pintar, maka pengembangan desa wisata digital di Indonesia dimulai dengan rencana strategis pembangunan desa pintar seperti pada Tabel 1 yang mencakup dimensi subsistem strategis yang menguraikan arah pengembangan masa depan dari subsistem sosial, subsistem ekonomi, subsistem sumber daya dan lingkungan, dan subsistem informasi.

Tabel 1. Perencanaan Strategis Desa Wisata Digital

\begin{tabular}{|c|c|c|}
\hline No. & Dimensi & Merencanakan Konten \\
\hline \multirow[t]{4}{*}{1} & \multirow[t]{4}{*}{$\begin{array}{l}\text { Subsistem } \\
\text { Strategis }\end{array}$} & $\begin{array}{l}\text { Visi: jadikan pariwisata } \\
\text { menjadi industri yang kuat, } \\
\text { jadikan desa menjadi destinasi } \\
\text { wisata yang menarik, dan } \\
\text { jadikan lingkungannya sebagai } \\
\text { rumah yang lestari untuk hidup. }\end{array}$ \\
\hline & & $\begin{array}{l}\text { Sasaran: pada tahun } 2025, \\
\text { kemajuan awal akan dibuat } \\
\text { dalam pembangunan desa } \\
\text { digital. Pada tahun 2030, } \\
\text { kemajuan utama akan dicapai } \\
\text { dalam pembangunan desa } \\
\text { wisata digital. Pada tahun 2035, } \\
\text { kemajuan besar akan dicapai } \\
\text { dalam pembangunan desa } \\
\text { wisata digital dan lingkungan } \\
\text { berkelanjutan. }\end{array}$ \\
\hline & & $\begin{array}{l}\text { Tugas: } \\
\text { pembangunan infrastruktur } \\
\text { informasi pedesaan, } \\
\text { mengoordinasikan } \\
\text { pengembangan } \\
\text { perkotaan dan pedesaan, } \\
\text { membangun desa digital dan } \\
\text { hijau, mengembangkan } \\
\text { pariwisata digital pedesaan, } \\
\text { mempromosikan tata kelola } \\
\text { digital di pedesaan, dan } \\
\text { memperkuat pasokan layanan } \\
\text { wisata digital. }\end{array}$ \\
\hline & & $\begin{array}{l}\text { Langkah-langkah implementasi: } \\
\text { memperkuat organisasi dan } \\
\text { kepemimpinan pemerintah } \\
\text { desa, memperkenalkan } \\
\text { kebijakan pendukung terkait, } \\
\text { melakukan demonstrasi } \\
\text { percontohan desa digital, } \\
\text { memperkuat dukungan berbagai } \\
\text { talenta dalam pembangunan } \\
\text { desa wisata digital, dan } \\
\text { menciptakan suasana yang } \\
\text { kondusif. }\end{array}$ \\
\hline
\end{tabular}




\begin{tabular}{|c|c|c|c|c|c|}
\hline No. & Dimensi & Merencanakan Konten & \multirow{6}{*}{ No. } & Dimensi & \multirow[b]{2}{*}{\begin{tabular}{l}
\multicolumn{3}{c}{ Merencanakan Konten } \\
pembangunan pusat big data \\
pariwisata dan pedesaan dan \\
seluruh rantai industri produk \\
pariwisata penting; dan (ii) \\
mendorong integrasi dan \\
penerapan TIK secara \\
mendalam dalam pengelolaan \\
industri pariwisata.
\end{tabular}} \\
\hline \multirow[t]{6}{*}{2} & \multirow[t]{6}{*}{$\begin{array}{l}\text { Subsistem } \\
\text { Sosial }\end{array}$} & \multirow{3}{*}{$\begin{array}{l}\text { Langkah-langkah } \text { terkait } \\
\text { pemerintahan desa digital } \\
\text { meliputi: (i) mewujudkan } \\
\text { keterbukaan urusan layanan } \\
\text { pedesaan online, desa dan } \\
\text { keuangan; (ii) mengandalkan } \\
\text { sistem platform berbagi dan } \\
\text { pertukaran data nasional untuk } \\
\text { mempromosikan pembagian, } \\
\text { pembukaan, dan integrasi yang } \\
\text { efektif dari sumber daya } \\
\text { informasi pariwisata di berbagai } \\
\text { departemen; dan (iii) } \\
\text { mengandalkan platform layanan } \\
\text { pemerintah online terintegrasi } \\
\text { nasional untuk mempercepat } \\
\text { promosi reformasi layanan e- } \\
\text { government di desa. }\end{array}$} & & \multirow{5}{*}{ Dincis } & \\
\hline & & & & & $\begin{array}{l}\text { Langkah-langkah terkait } e \text { - } \\
\text { commerce desa meliputi: (i) } \\
\text { melaksanakan proyek berbasis } \\
\text { digital dalam pariwisata; (ii) } \\
\text { membangun sejumlah pusat } \\
\text { informasi pariwisata digital; } \\
\text { dan (iii) menumbuhkan merek } \\
\text { produk e-commerce desa } \\
\text { wisata. }\end{array}$ \\
\hline & & & & & \multirow{3}{*}{$\begin{array}{l}\text { Langkah-langkah terkait desa } \\
\text { wisata digital meliputi: (i) } \\
\text { mengembangkan format bisnis } \\
\text { baru seperti kerajinan kreatif, } \\
\text { pemandangan alam digital, } \\
\text { inovasi hasil pertanian, tamasya } \\
\text { desa, budaya lokal, heritage } \\
\text { desa yang dibuat dalam paket- } \\
\text { paket wisata; dan (ii) } \\
\text { mempromosikan } \\
\text { pengembangan industri } \\
\text { pariwisata baru yang } \\
\text { terintegrasi dengan seluruh } \\
\text { potensi desa seperti rekreasi, } \\
\text { produksi energi, kesehatan, dan } \\
\text { homestay yang kreatif. }\end{array}$} \\
\hline & & $\begin{array}{l}\text { Langkah-langkah terkait } \\
\text { pendidikan pada desa digital } \\
\text { meliputi: (i) mewujudkan } \\
\text { cakupan jaringan broadband } \\
\text { penuh di lembaga pendidikan; } \\
\text { dan (ii) mewujudkan hubungan } \\
\text { antara sumber daya pendidikan } \\
\text { tinggi di perkotaan dengan } \\
\text { sekolah dasar dan menengah di } \\
\text { pedesaan. }\end{array}$ & & & \\
\hline & & \multirow{2}{*}{$\begin{array}{l}\text { Langkah-langkah terkait } \\
\text { perawatan medis desa digital } \\
\text { meliputi: (i) mendukung } \\
\text { institusi medis tingkat } \\
\text { kota/kabupaten dan desa untuk } \\
\text { meningkatkan informasi; dan } \\
\text { (ii) mewujudkan penyelesaian } \\
\text { langsung asuransi kesehatan } \\
\text { dan transfer online dan } \\
\text { kelanjutan hubungan asuransi } \\
\text { sosial bagi penduduk } \\
\text { kota/kabupaten dan desa untuk } \\
\text { perawatan medis di tempat yang } \\
\text { berbeda. }\end{array}$} & & & \\
\hline & & & \multirow[t]{3}{*}{4} & \multirow[t]{3}{*}{$\begin{array}{l}\text { Subsistem } \\
\text { Sumber } \\
\text { Daya dan } \\
\text { Lingkungan }\end{array}$} & \multirow{2}{*}{$\begin{array}{l}\text { Mempromosikan metode } \\
\text { produksi pariwisata digital dan } \\
\text { hijau, seperti membangun } \\
\text { sistem pengawasan } \\
\text { ketertelusuran elektronik untuk } \\
\text { input wisatwan guna } \\
\text { mempromosikan produk } \\
\text { pariwisata dan menggunakan } \\
\text { teknologi Internet of Things } \\
\text { (IoT) untuk memantau aktivitas } \\
\text { pariwisata secara real time dan } \\
\text { mempromosikan konservasi } \\
\text { lingkungan. }\end{array}$} \\
\hline \multirow[t]{2}{*}{3} & \multirow[t]{2}{*}{$\begin{array}{l}\text { Subsistem } \\
\text { Ekonomi }\end{array}$} & \multirow{2}{*}{$\begin{array}{l}\text { Langkah-langkah terkait } \\
\text { pariwisata digital meliputi: (i) } \\
\text { meletakkan dasar untuk } \\
\text { pengembangan pariwisata } \\
\text { digital dalam semua aspek, } \\
\text { seperti meningkatkan "satu } \\
\text { gambaran" pemantauan } \\
\text { penginderan jauh sumber daya } \\
\text { lam dan platform pengawasan } \\
\text { yang komprehensif, } \\
\text { membangun fasilitas berbasis } \\
\text { ruang seperti satelit } \\
\text { penginderaan jauh untuk } \\
\text { pariwisata dan daerah pedesaan, } \\
\text { dan mempromosikan }\end{array}$} & & & \\
\hline & & & & & $\begin{array}{l}\text { Lindungi lingkungan ekologi } \\
\text { pedesaan dengan TIK. } \\
\text { Langkah-langkah } \\
\text { meliputi (i) membangun } \\
\text { platform pemantauan ekosistem } \\
\text { pedesaan nasional; (ii) } \\
\text { memperkuat pemantauan dan } \\
\text { perlindungan lingkungan } \\
\text { ekologi yang digunakan untuk } \\
\text { aktivitas pariwisata; dan (iii) } \\
\text { menggunakan teknologi satelit, }\end{array}$ \\
\hline
\end{tabular}




\begin{tabular}{|c|c|c|}
\hline No. & Dimensi & Merencanakan Konten \\
\hline & & $\begin{array}{l}\text { pesawat tak berawak, dan } \\
\text { sistem pemantauan video jarak } \\
\text { jauh untuk menerapkan } \\
\text { pemantauan utama pada area } \\
\text { ekosistem pedesaan dan tempat } \\
\text { wisata yang rentan dan sensitif. }\end{array}$ \\
\hline & & $\begin{array}{l}\text { Membangun platform } \\
\text { pemantauan yang komprehensif } \\
\text { untuk lingkungan pemukiman } \\
\text { pedesaan yang bisa melindungi } \\
\text { kualitas sumber daya alam di } \\
\text { desa, serta pemantauan penuh } \\
\text { waktu terhadap polutan dan } \\
\text { sumber polusi pedesaan. }\end{array}$ \\
\hline \multirow[t]{3}{*}{5} & \multirow[t]{3}{*}{$\begin{array}{l}\text { Subsistem } \\
\text { Informasi }\end{array}$} & $\begin{array}{l}\text { Untuk meningkatkan tingkat } \\
\text { fasilitas jaringan desa wisata } \\
\text { digital meliputi: (i) memperkuat } \\
\text { pembangunan bersama dan } \\
\text { berbagi infrastruktur dan } \\
\text { mempercepat pengembangan } \\
\text { jaringan komunikasi pita lebar } \\
\text { pedesaan, internet seluler, } \\
\text { jaringan televisi digital, dan } \\
\text { internet generasi berikutnya } \\
\text { untuk pengembangan desa } \\
\text { wisata; (ii) mendukung } \\
\text { pengembangan jaringan pita } \\
\text { lebar di pedesaan; dan (iii) } \\
\text { mempromosikan dasar-dasar } \\
\text { dan peningkatan fasilitas } \\
\text { penyiaran dan televisi di daerah } \\
\text { pedesaan. }\end{array}$ \\
\hline & & $\begin{array}{lr}\text { Meningkatkan } & \text { penyediaan } \\
\text { terminal dan layanan informasi, } \\
\text { terutama dengan mendorong } \\
\text { pengembangan } \\
\text { informasi, produk teknis, dan } \\
\text { paket perangkat lunak aplikasi } \\
\text { (app) internet seluler yang } \\
\text { disesuaikan } \\
\text { karakteristik dengan } \\
\text { pedesaan, dan obyek wisata". }\end{array}$ \\
\hline & & $\begin{array}{l}\text { Mempercepat transformasi } \\
\text { digital infrastruktur pedesaan, } \\
\text { yaitu mengembangkan smart } \\
\text { water conservancy, smart } \\
\text { transportasi, smart grids, smart } \\
\text { farming, dan smart logistics di } \\
\text { pedesaan untuk peningkatan } \\
\text { pariwisata. }\end{array}$ \\
\hline
\end{tabular}

Sumber:

Diolah dari The General Office of the Central Committee of the Communist Party of China and the General Office of the State Council 2019; Zhang \& Zhang (2020).
Dengan demikian, desa wisata digital sebagai desa yang memanfaatkan TIK dalam pengembangan ekosistem wisatanya dan proses penggunaan teknologi digital dan data-data untuk pengelolaan dan pengembangan desa wisata (mengoptimalkan proses internal, otimatisasi kerja, dan peminimalan kertas dan biaya). Dalam prosesnya, desa wisata digital memulai proses digitalisasi, yaitu proses alih media dari bentuk tercetak, audio, maupun video menjadi bentuk digital, untuk membuat arsip dokumen bentuk digital, dan proses pemberian atau pemakaian sistem digital, dan proses digitisasi, yaitu proses mengkonversi dari analog menuju digital. Hal ini dapat dicontohkan pada desa Desa Wisata Tinalah, Kulonprogo, Yogyakarta yang mampu melakukan optimalisasi potensi wisata alam dan budaya dengan memanfaatkan teknologi digital (https://www.dewitinalah.com/). Jadi berbagai macam informasi dan data yang tadinya bersifat manual dan konvensional dipindahkan dalam format digital. Digitisasi merujuk pada pengoptimalan proses internal, misalnya otomatisasi kerja, peminimalan kertas, dsb. dengan tujuan untuk mengurangi biaya (Jaelani, et al., 2020; Wirdayanti, 2021)).

Dalam transformasi menjadi desa wisata digital, maka proses digitasi dan digitalisasi berlangsung secara bersamaan. Trasformasi digital di desa wisata akan mengubah usaha/bisnis desa wisata semakin optimal, efisien, dan efektif. Pada sisi lain, transformasi digital menuntut pengadopsian teknologi digital yang lebih luas lagi dan ada perubahan budaya didalamnya, yaitu pada manusia daripada teknologi digitalnya. Tujuannya untuk meneingkatkan kecepatan layanan pariwisata di desa. Secara proses, transformasi digital harus dilakukan secara end-to-end (ujung ke ujung) dan secara terintegrasi antara satu komponen dengan yang lainnya. Tujuannya agar transformasi digital dapat menciptakan suatu nilai (value 
creation) yang meningkatkan kemanfaatan bagi semua pihak, penurunan risiko dan efisiensi penggunaan sumber daya yang terbatas. Nilai kemanfaatan yang dirasakan oleh para pihak misalnya kemudahan, kecepatan dan biaya yang rendah. Penurunan risiko sangat penting untuk mengurangi kejadian kegagalan atau kesalahan jalannya proses termasuk juga menghindari potensi gangguan yang mungkin terjadi. Pemanfaatan TIK juga harus memperhatikan efisiensi penggunaan sumber daya, misalnya ketersediaan dana dan SDM yang ada di desa.

Transformasi digital mencakup beberapa aspek, yaitu kebijakan-kebijakan nasional terkait desa wisata, pengaturan proses bisnis yang sesuai, kelembagaan desa yang lebih cocok, kebiasaan atau adat desa, informasi desa, ketersediaan infrastruktur dan aplikasi, SDM desa yang memadai
(Layaman et al., 2021; Jaelani, 2018). Digitalisasi desa wisata yang merupakan kewenangan desa harus menjadi prioritas dalam RPJM Desa dan RKP Desa dan teranggarkan dalam bidang pariwisata dan informasi bidang pendukungnya yang teranggarkan di APBDesa berdasarkan Permendagri RI 20 Tahun 2018. Pemanfaatan TIK berdasarkan pengaturan proses bisnis yang sesuai, dengan mengubah prosedur-prosedur teknis, proses perekaman/pencatatan data, proses transaksi keuangan dan lain-lainnya (Jaelani, 2018a). Perubahan proses bisnis ini dilakukan berdasarkan hasil analisis proses bisnis yang dilakukan sebelumnya (Permendagri RI Nomor 114 Tahun 2014).

Adapun teknik membangun desa wisata digital dapat diilustrasikan pada Gambar 3 berikut ini:

Teknik Membangun Desa Wisata Digital

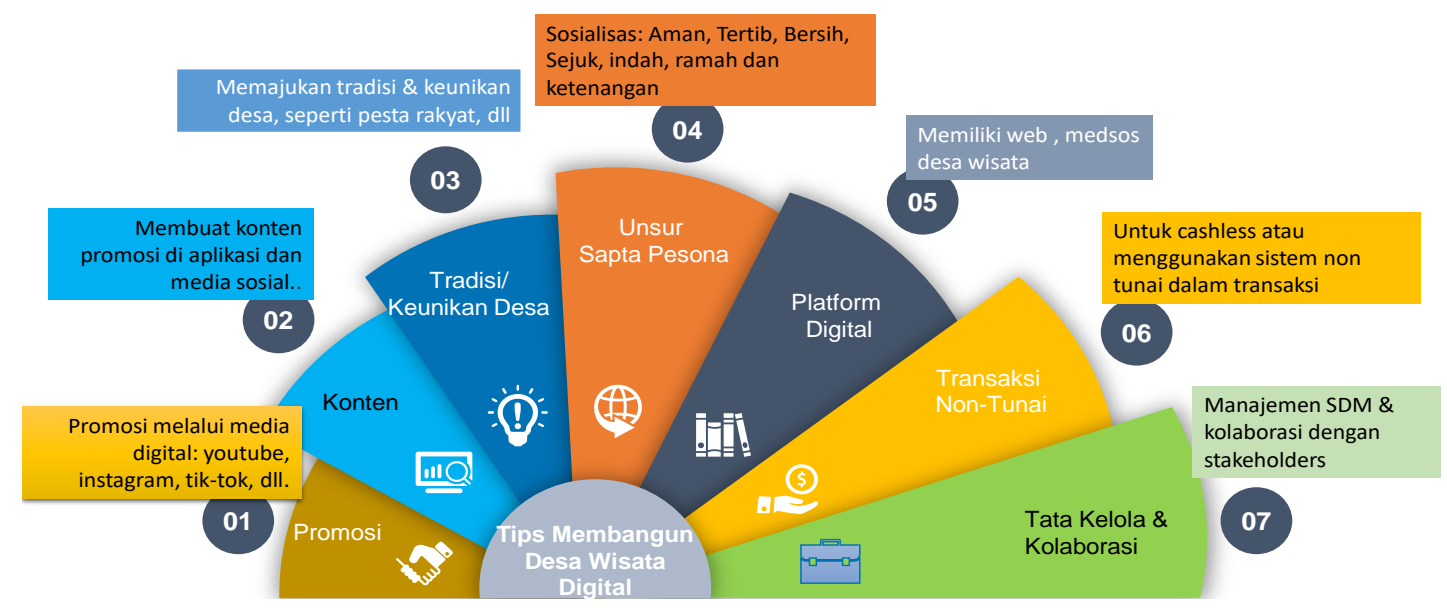

Gambar 4. Teknik Membangun Desa Wisata Digital

Sementara itu, proses digitalisasi desa wisata berupa pemanfaatan TIK dan media digital dengan memerhatikan pada:

1) penggunaan TIK harus menyentuh proses digitalisasi informasi, yaitu wisata dikemas dalam media-media digital dalam kegiatan promosi (mudah, murah, aman, dan tepat waktu);

2) informasi wisata yang lengkap mencakup: (a) pemesanan paket perjalanan wisata oleh wisatawan (booking); (b) identitas wisatawan (demografi dan status sosio-ekonomi); 
(c) jadwal keterisian kamar maupun jadwal kunjungan wisatawan; (d) transaksi wisatawan selama di desa wisata (keuangan digital inklusif), dan (e) desa wisata go digital, e-commerce, industri kreatif; dan (f) kritik, masukan, dan saran untuk peningkatan layanan;

3) Aspek SDM desa harus ditingkatkan dalam penggunaan perangkat digital dan pemanfaatan informasi digital melalui pelatihan teknis sebagai administrator atau pengguna akhir;

4) Pemanfaatan informasi digital dapat dilakukan dengan literasi konten digital, biasanya terkait kehati-hatian dengan konten negatif dan hoax. SDM di desa juga harus mampu menjalankan proses mitigasi jika ada penyalahgunaan konten;

5) Digitalisasi internal desa wisata dapat berupa pemanfaatan TIK dalam pengelolaan organisasi: (a) media sosial dan media chating (seperti whatsapp, facebook, dan twitter) dapat digunakan untuk melakukan edukasi bagi anggota desa wisata dan masyarakat di desa mengenai "sadar wisata" dan "sapta pesona"; (b) video dan materi edukasi berupa modul format pdf dapat didistribusikan melalui media digital dan online; (c) membuat bahan ajar berbasis web; (d) membuat kuis online untuk menguji pemahaman anggota dan masyarakat terkait dengan desa wisata; dan (e) pengelolaan keuangan dan daftar kehadiran pengelola via aplikasi mobile.

\section{KESIMPULAN}

Pemanfaatan teknologi digital dalam pengembangan pariwisata dan keberlanjutan lingkungan menjadi bagian yang integral dalam pembangunan berkelanjutan di desa. Perencanaan strategis dan praktik desa digital sangat penting untuk mempercepat transformasi desa wisata menjadi desa wisata digital yang memerhatikan karakteristik, potensi, dan kebutuhan pembangunan desa. Dengan teori sistem, maka pengembangan desa wisata digital dapat diwujudkan melalui adopsi teknologi, informasi, dan komunikasi dalam pembangunan berkelanjutan di desa secara kompleks dan terintegrasi dengan aspekaspek lainnya, sehingga kelima subsistem dari sistem desa pintar atau desa digital, yaitu subsistem strategis, subsistem sosial, subsistem ekonomi, subsistem sumber daya dan lingkungan, dan subsistem informasi menunjukkan perencanaan yang komprehensif untuk menyelesaikan persoalan dalam pengembangan desa wisata digital di Indonesia.

Dengan perspektif mikroanalisis komprehensif yang sistematis sebagai metode yang digunakan untuk menganalisis subsistem dan hubungan antar subsistem dalam sistem yang kompleks dapat menunjukkan ruang-ruang terpadu sebagai syarat mewujudkan desa wisata digital. Hal ini menuntut pula adanya pembangunan pariwisata yang melibatkan banyak stakeholders dan kapasitas teknologi digital yang mampu menghubungkan antar komponen dalam pengelolaan pariwisata di desa. Desa wisata digital akan mengubah proses bisnis desa wisata semakin optimal, efisien, dan efektif. Transformasi digital ini akan meningkatkan layanan pariwisata dengan cepat, perubahan budaya pada masyarakat, dan promosi lingkungan agar tetap lestari, sehingga desa dapat mencapai pembangunan berkelanjutan.

\section{DAFTAR PUSTAKA}

Adamowicz, M., \& Zwolińska-Ligaj, M. (2020). The "Smart Village" as a way to achieve sustainable development in rural areas of Poland. Sustainability, 12(16), 6503.

Adamowicz, M., \& Zwolińska-Ligaj, M. (2020). The "Smart Village" as a way to achieve sustainable development in rural areas of Poland. Sustainability, 12(16), 6503.

Adnyana, I. M. (2020). Dampak Green Tourism Bagi Pariwisata Berkelanjutan Pada Era Revolusi Industri 4.0. Jurnal Ilmiah MEA 
(Manajemen, Ekonomi, \& Akuntansi), 4(3), 1582-1592.

Aji, R. R. (2021). Pengembangan Pariwisata Alam dalam Mendukung Pembangunan Berkelanjutan di Desa Wisata Pentingsari. Jurnal Perencanaan Wilayah dan Kota, 16(2), 9-17.

Al Banjari, H. (2021). Buku panduan praktis: 10 langkah mengembangkan desa wisata hijau. Deutsche Gesellschaft für Internationale Zusammenarbeit (GIZ) GmbH.

As' Adi, M., Zaman, A. N., Dewi, A. C., Viacenza, A. N., \& Montreano, D. (2020). Kajian Model Desain Aplikasi Mobile yang Berkelanjutan pada Desa Wisata. Jurnal Manajemen Industri dan Logistik, 4(1), 47-57.

Auyang, S. Y. (1998). Foundations of complex-system theories: in economics, evolutionary biology, and statistical physics. Cambridge University Press.

Brahimi, T., \& Bensaid, B. (2019). Smart Villages and the GCC Countries: Policies, Strategies, and Implications. In Smart Villages in the EU and Beyond. Emerald Publishing Limited.

Budiani, S. R., Wahdaningrum, W., Yosky, D., Kensari, E., Pratama, H. S., Mulandari, H., \& Kusmiati, Y. (2018). Analisis Potensi Dan Strategi Pengembangan Pariwisata Berkelanjutan Berbasis Komunitas Di Desa Sembungan, Wonosobo, Jawa Tengah. Majalah Geografi Indonesia, 32(2), 170-176.

Calomino, D. (2020). Sharing economy and villages' development through the application of technology: the Italian case. In The Emerald Handbook of ICT in Tourism and Hospitality. Emerald Publishing Limited.

Cohen, S. A., Higham, J. E. S., Gossling, S., \& Peeters, P. eds. (2014). Understanding and governing sustainable tourism mobility: psychological and behavioural approaches. Routledge, 2014

Della Corte, V., Del Gaudio, G., Sepe, F., \& Sciarelli, F. (2019). Sustainable tourism in the open innovation realm: A bibliometric analysis. Sustainability, 11(21), 6114.

Dewi, N. I. K. (2020). Photogrammetry dalam Perancangan: Pemetaan dan Pemodelan Kawasan Desa Wisata. Jurnal Arsitektur TERRACOTTA, 2(1).

Directorate-General for Agriculture and Rural Development (European Commission), ECORYS. (2019). Pilot Project: Smart Eco-Social Villages: Final Report;, Origin For Sustainability, R.E.D: Brussels, Belgium, April 2019.

Edwards, M. M., \& Haines, A. (2007). Evaluating smart growth: Implications for small communities. Journal of planning education and research, 27(1), 49-64.

European Commission. EU Action for Smart Villages, 12 April 2017. Available online: http://enrd.ec.europa.eu (acc essed on 30 May 2018).

Fauziah, N. R., \& Nasdian, F. T. (2021). Hubungan Antara Partisipasi Masyarakat Dengan Pemanfaatan Digital Pada Desa Wisata. Jurnal Sains Komunikasi dan Pengembangan Masyarakat [JSKPM], 5(1), 189-201.

Frey, B. S., \& Briviba, A. (2021). A policy proposal to deal with excessive cultural tourism. European Planning Studies, 29(4), 601-618.

Gao, X., Guo, X., \& Lo, T. (2021). Digital Infrastructure-A Potential Method for Rural Revitalization through Digitization of Rural Information.

Garau, C. (2015). Perspectives on cultural and sustainable rural tourism in a smart region: The case study of Marmilla in Sardinia 
(Italy). Sustainability, 7(6), 64126434.

Gascó-Hernandez, M. (2018). Building a smart city: Lessons from Barcelona. Communications of the ACM, 61(4), 50-57.

Geria, A. A. G. A., Maheswari, A. A., \& Pemayun, A. A. (2018). Social media as promotion trend for increasing tourist visit towards digital era. International Journal of Social Sciences and Humanities, 2(3), 86-94.

Glasmeier, A., \& Christopherson, S. (2015). Thinking about smart cities. Cambridge Journal of Regions, Economy and Society, 8(1), 3-12.

Gomez-Oliva, A., Alvarado-Uribe, J., ParraMeroño, M. C., \& Jara, A. J. (2019). Transforming communication channels to the co-creation and diffusion of intangible heritage in smart tourism destination: Creation and testing in ceutí (spain). Sustainability, 11(14), 3848.

Gomez-Trujillo, A. M., \& Gonzalez-Perez, M. A. (2021). Digital transformation as a strategy to reach sustainability. Smart and Sustainable Built Environment.

Gorain, B. K. (2022). Leveraging Physical, Digital and Knowledge Connectivity for Smart Villages. In Smart Villages (pp. 153-175). Springer, Cham.

Handayani, T., \& Rahmi, M. (2018). Analisis Kesiapan Desa Mekar Agung Kecamatan Cibadak Kabupaten Lebak Banten Sebagai Desa Wisata Syariah. Ikra-Ith Ekonomika, 1(2), 112.

Hayat, P. (2016). Smart cities: A global perspective. India Quarterly,72(2), 177-191.

Hidayati, K., \& Nugrahani, H. S. D. (2021). Pengelolaan Desa Wisata Bahari Berkelanjutan dalam Perspektif Ketahanan Nasional. Jurnal of Admiration, 2(1), 94-103.
Huggins, C. (2018). Land-use planning, digital technologies, and environmental conservation in Tanzania. The Journal of Environment \& Development, 27(2), 210-235.

Istanti, L. N. (2021, November). Rural Tourism Perspectives on Digital Innovation: Small Enterprises in Indonesia. In BISTIC Business Innovation Sustainability and Technology International Conference (BISTIC 2021) (pp. 70-75). Atlantis Press.

Jaelani, A. (2013). Institusi pasar dan hisbah: Teori pasar dalam sejarah pemikiran ekonomi Islam. Syari'ah Nurjati Press.

Jaelani, A. (2018). Sistem anggaran berbasis kinerja pada APBN di Indonesia perspektif ekonomi Islam. Al-Amwal: Jurnal Ekonomi dan Perbankan Syari'ah, 10(1), 128-145.

Jaelani, A. (2018a). Public expenditure management in indonesia. HUNAFA: Jurnal Studia Islamika, 15(2), 189224.

Jaelani, A. (2021). Membangun Desa Wisata Digital. Disampaikan pada Gerakan Nasional Literasi Digital 2021. Kominfo RI, Selasa, 19 Oktober 2021 (Tidak dipublikasikan).

Jaelani, A., \& Hanim, T. F. (2020). Sustainability of Public Finance During The COVID-19 Outbreaks in Indonesia. Al-Amwal: Jurnal Ekonomi dan Perbankan Syari'ah, 12(1), 109123.

Jaelani, A., \& Setyawan, E., Hasyim, N. (2017). Religi, budaya dan ekonomi kreatif: Prospek dan pengembangan pariwisata halal di Cirebon. AlMustashfa: Jurnal Penelitian Hukum Ekonomi Syariah, 2(2), 101-122.

Jaelani, A., Setyawan, E., Aziz, A., Wahyuningsih, N., \& Djuwita, D. (2020). Sustainable Event and Festival In Cirebon, Indonesia: In Islamic Marketing Perspective/Evento y 
Festival Sostenible en Cirebon, Indonesia: En Perspectiva del Marketing Islámico. ROSA DOS VENTOS-Turismo Hospitalidade, 12(4).

Kahfi, A., \& Sarjan, M. (2020). Implementasi Peta Digital untuk Smart Village (Studi Kasus Desa Tammangalle, Polewali Mandar). Jurnal Ilmiah Ilmu Komputer Fakultas Ilmu Komputer Universitas Al Asyariah Mandar, 6(1), 13-18.

Katsoni, V., \& Spyriadis, T. (2020). Cultural and Tourism Innovation in the Digital Era. Springer International Publishing.

Kumar, V., \& Sikarwar, S. (2017). Smart concepts for integrated rurban development of historical towns in India: Case of Panipat, Haryana. In From Poverty, Inequality to Smart City (pp. 57-81). Springer, Singapore.

Kurniawan, A. R. (2020). Tantangan Pengembangan Pariwisata Berbasis Masyarakat pada Era Digital di Indonesia (Studi Kasus Pengembangan Pariwisata Berbasis Masyarakat di Pangalengan). Tornare: Journal of Sustainable and Research, 2(2), 10.

Laxmita, N. A., Setyaningsih, W., \& Purwani, O. (2021, May). Sustainable rural tourism development in the era of social media shape identities and discourse digital settings. In IOP Conference Series: Earth and Environmental Science (Vol. 778, No. 1, p. 012010). IOP Publishing.

Layaman, L., Harahap, P., Djastuti, I., Jaelani, A., \& Djuwita, D. (2021). The mediating effect of proactive knowledge sharing among transformational leadership, cohesion, and learning goal orientation on employee performance. Business: Theory and Practice, 22(2), 470-481.
Lee, P., Hunter, W. C., \& Chung, N. (2020). Smart tourism city: Developments and transformations. Sustainability, 12(10) , 3958.

Lin, H. H. (2021). Research on the Development of Religious Tourism and the Sustainable Development of Rural Environment and Health.

Liu, Y. Y., \& Mačerinskienè, A. (2016). Managing the Digital Campaign Process for Sustainable Tourism Destination. WIT Trans. Ecol. Environ, 201, 139-153.

Maja, P. W., Meyer, J., \& Von Solms, S. (2020). Development of Smart Rural Village Indicators in Line With Industry 4.0. IEEE Access, 8, 152017152033.

Martínez-Graña, A. M., Serrano, L., González-Delgado, J. A., Dabrio, C. J., \& Legoinha, P. (2017). Sustainable geotourism using digital technologies along a rural georoute in Monsagro (Salamanca, Spain). International journal of digital earth, 10(2), 121138.

Maulidia, H. (2019). Implementasi Program Smart Kampung (Desa Tamansari Kecamatan Licin Kabupaten Banyuwangi) (Doctoral dissertation, Universitas Muhammadiyah Jember).

McGinnis, G., Harvey, M., \& Young, T. (2020). Indigenous knowledge sharing in Northern Australia: Engaging digital technology for cultural interpretation. Tourism Planning \& Development, 17(1), 96-125.

Mohanty, S., Mohanta, B., Nanda, P., Sen, S., \& Patnaik, S. (2020). Smart Village Initiatives: An Overview. Smart Village Technology, 3-24.

Nadra, A. K. (2021). Tinjauan Pengembangan Desa Wisata Rantih Kota Sawahlunto Dengan Pendekatan Pariwisata Berkelanjutan. Jurnal Pariwisata Bunda, 2(1), 13-20.

Naldi, L., Nilsson, P., Westlund, H., \& Wixe, S. (2015). What is smart rural 
development?. Journal of rural studies, 40, 90-101.

Namono, C. (2018). Digital technology and a community framework for heritage rock art tourism, Makgabeng Plateau, South Africa. African Archaeological Review, 35(2), 269-284.

Nikmawati, E. E., Widiaty, I. S. M. A., Achdiani, Y. A. N. I., Hurriyati, R. A. T. I. H., \& Mubaroq, S. R. (2019). Educational digital media for traditional food of Kampung adat cireundeu: An ethnopedagogy perspective. J. Eng. Sci. Technol, 14, 2540-2551.

Njovo, M., \& Makacha, C. (2018). Cultural capital, digital capital and stakeholder partnerships: a holy trinity for a sustainable cultural tourism trajectory. African Journal of Hospitality, Tourism and Leisure, 7(5), 1-13.

Notarstefano, G., \& Gristina, S. (2021). Eco-Sustainable Routes and Religious Tourism: An Opportunity for Local Development. The Case Study of Sicilian Routes. In Tourism in the Mediterranean Sea. Emerald Publishing Limited.

Nugraha, A. R., Novianti, E., Komala, L., Lukman, S., \& Sjoraida, D. F. (2019). Pelatihan Media Online Dalam Upaya Meningkatkan Melek Informasi Kalangan Milineal pada Program Pembangunan di Desa Purbahayu. JPM (Jurnal Pemberdayaan Masyarakat), 4(2), 314-321.

Patnaik, S., Sen, S., \& Mahmoud, M. S. (Eds.). (2020). Smart Village Technology: Concepts and Developments (Vol. 17). Springer Nature.

Pérez-delHoyo, R., \& Mora, H. (2019). Toward a New Sustainable Development Model for Smart Villages. In Smart Villages in the EU and Beyond. Emerald Publishing Limited.

Pradana, G. Y. K., \& Arcana, K. T. P. (2020). Balinese traditional homestay in a sustainable tourism entering millennial era.Journal of Xi'an University of Architecture \& Technology, 12(3), 4208-4217.

Purnomo, S., Rahayu, E. S., RIANI, A. L., SUMINAH, S., \& Udin, U. D. I. N. (2020). Empowerment model for sustainable tourism village in an emerging country. The Journal of Asian Finance, Economics, and Business, 7(2), 261-270.

Puspawati, D. P. H., \& Ristanto, R. (2018). Strategi Promosi Digital Untuk Pengembangan Pariwisata Kota Magelang. Jendela Inovasi Daerah, 1(2), 1-20.

Rachmadi, M. F. (2020). Analisis Optimalisasi Teknologi Digital di Era Revolusi Industri 4.0 dalam Mengembangkan Kawasan Industri Pariwisata Halal guna Meningkatkan Perekonomian Lokal Kecamatan Gunungpati Kota Semarang. Jurnal DinamikA, 1(1), 39-53.

Rachmat, A. (2021). Branding Event Budaya Perang Tomat Di Desa Cikidang Menjadi Destinasi Wisata Berkelanjutan Melalui Strategi Media Komunikasi. Jurnal Heritage,9(1), 149-161.

Rachmawati, R. (2018). Pengembangan Smart Village untuk Penguatan Smart City Dan Smart Regency. Jurnal Sistem Cerdas, 1(2), 12-19.

Raldianingrat, W., \& Fitria, F. (2021). Kajian Model Desa Cerdas (Smart Village) berbasis Satu Desa Satu Greenhouse pada Wilayah Pusat Pertumbuhan Desa di Kabupaten Konawe. Jurnal Ilmiah Dikdaya, 11(2), 278-288.

Ramadhian, N. (2021). Berapa Jumlah Desa Wisata di Indonesia?. Kompas.com. Minggu, 1 Agustus 2021. 
https://travel.kompas.com/read/2021/0 8/01/180600927/.

Ricart, S., Ribas, A., Pavón, D., GabardaMallorquí, A., \& Roset, D. (2019). Promoting historical irrigation canals as natural and cultural heritage in mass-tourism destinations. Journal of Cultural Heritage Management and Sustainable Development.

Rochman, G. P., Chofyan, I., \& Sakti, F. (2020, February). Understanding the smart society in rural development. In IOP Conference Series: Earth and Environmental Science (Vol. 447, No. 1, p. 012016). IOP Publishing.

Romolini, A., Fissi, S., \& Gori, E. (2017). Integrating territory regeneration, culture and sustainable tourism. The Italian albergo diffuso model of hospitality. Tourism management perspectives, 22, 67-72.

Rudwiarti, L. A., Pudianti, A., Emanuel, A. W. R., Vitasurya, V. R., \& Hadi, P. (2021, May). Smart tourism village, opportunity, and challenge in the disruptive era. In IOP Conference Series: Earth and Environmental Science (Vol. 780, No. 1, p. 012018). IOP Publishing.

Rumiati, A. T., Gunawan, J., \& Trisunarno, L. (2021). Proses Partisipatif dalam Pemetaan Desa untuk Pembangunan Berkelanjutan di Kawasan Sekawan Sejati Lombok Barat, Nusa Tenggara Barat. SEWAGATI, 5(2), 176-182.

Sapta, I. K. S., Landra, N., Supartha, I. W. G., Asih, D., \& Setini, M. (2020). Public health welfare in digital-based resources transformation from social capital and information sharing: Creative industries from village. Systematic Reviews in Pharmacy, 11(6), 688-696.

Saputra, M. A., \& Isnain, A. R. (2021). Penerapan Smart Village Dalam Peningkatan Pelayanan Masyarakat Menggunakan Metode Web Engeneering (Studi Kasus: Desa
Sukanegeri Jaya). Jurnal Teknologi dan Sistem Informasi, 2(3), 49-55.

Sary, K. A., Purwanti, S., \& Juwita, R. (2021). Implementation of Smart Tourism in Kedang Ipil Village. Budapest International Research and Critics Institute (BIRCIJournal): Humanities and Social Sciences, 4(3), 4862-4872.

Sigala, M., \& Leslie, D. (2006). Conclusion The future of the past: visions and trends for cultural tourism sector. International Cultural Tourism, 234, 240.

Sitorus, D. H. (2020). Community-Based Tourism Dimension Approach: The Existence of Digital Marketing in the Coastal Communities of the Riau Islands Province. Jurnal Mantik, 4(3), 2342-2347.

Soeswoyo, D. M. (2021). Potensi Pariwisata Dan Strategi Pengembangan Desa Wisata Sukajadi di Kabupaten Bogor. Masyarakat Pariwisata: Journal of Community Services in Tourism, 2(1), 13-26.

Srivatsa, P. (2015). Rural urban migration: disturbing the equilibrium between smart cities and smart villages. FIIB Business Review, 4(3), 3-10.

Stojanova, S., Lentini, G., Niederer, P., Egger, T., Cvar, N., Kos, A., \& Stojmenova Duh, E. (2021). Smart Villages Policies: Past, Present and Future. Sustainability, 13(4), 1663.

Subejo, S., Chamidah, N., Nirmalasari, N., Suyoto, S., Hariadi, S. S., Muhamad, M., ... \& Isamayana, I. (2021). Strategi Komunikasi Dan Pemanfaatan Teknologi Informasi Dan Komunikasi Dalam Pengembangan Ketahanan Desa Wisata Pada Masa Pandemi Covid-19 Di Cirebon. Jurnal Ketahanan Nasional, 27(1), 90-111.

Subekti, T., \& Damayanti, R. (2019). Penerapan model smart village dalam pengembangan desa wisata: Studi 
pada desa wisata boon pring sanankerto turen kabupaten malang. Journal of Public Administration and Local Governance, 3(1), 18-28.

Sugandi, Y. B. W., Paturusi, S. A., \& Wiranatha, A. S. (2020). Community Based Homestay Management in The Village Tourism of Tete Batu, Lombok. E-Journal of Tourism, 7(2), 369-383.

Sulistyaningsih, T., Jainuri, J., Salahudin, S., Jovita, H. D., \& Nurmandi, A. (2021). Can Combined Marketing and Planning-oriented of Communitybased Social Marketing (CBSM) Project Successfully Transform the Slum Area to Tourism Village? A Case Study of the Jodipan Colorful Urban Village, Malang, Indonesia. Journal of Nonprofit \& Public Sector Marketing, 1-30.

Suprapto, P. A. (2021). Pengembangan Desa Wisata Berbasis Green Tourism Di Desa Wisata Bakas, Banjarangkan, Klungkung. Dharmakarya, 10(2).

The General Office of the Central Committee of the Communist Party of China and the General Office of the State Council issued the "Digital Rural Development Strategy Outline". Available online: http://www.gov.cn/zhengce/2019-05/16/ content_5392269.htm (accessed on 16 May 2019).

Tongdhamachart, N. (2017). Challenges of Thailand Digital Economy Towards Community Tourism Development: Case Study of Baan Yafu, Maeyao District, Chiangrai Province. Actual Economy: Social Challenges and Financial Issues in XXI century (ACEFIIS: 2017). ACE.

Vaishar, A., \& Št’astná, M. (2019). Smart village and sustainability. Southern Moravia case study. European Countryside.
Wirdayanti, A. (2021). Pedoman desa wisata. Kementerian Koordinator Bidang Kemaritiman dan Investasi RI. Yasir, Y., Firzal, Y., Sulistyani, A., \& Yesicha, C. (2021). Penta helix communication model through community based tourism (CBT) for tourism village development in Koto Sentajo, Riau, Indonesia. GeoJournal of Tourism and Geosites, 37(3), 851860.

Yasmine, B., Putri, B., Chandra, N., \& Zuhdi, R. (2021). Konsep Sustainability Tourism Dengan Tema Smart Cultural Tourism Pada Desa Penglipuran, Bali. MATRAPOLIS: Jurnal Perencanaan Wilayah dan Kota, 2(1), 7-15.

Zavratnik, V., Kos, A., \& Stojmenova Duh, E. (2018). Smart villages: Comprehensive review of initiatives and practices. Sustainability, 10(7), 2559.

Zavratnik, V., Kos, A., \& Stojmenova Duh, E. (2018). Smart villages: Comprehensive review of initiatives and practices. Sustainability, 10(7), 2559.

Zavratnik, V., Podjed, D., Trilar, J., Hlebec, N., Kos, A., \& Stojmenova Duh, E. (2020). Sustainable and communitycentred development of smart cities and villages. Sustainability, 12(10), 3961.

Zhang, X., \& Zhang, Z. (2020). How do smart villages become a way to achieve sustainable development in rural areas? Smart village planning and practices in China. Sustainability, 12(24), 10510.

Zhang, X., \& Zhang, Z. (2020). How do smart villages become a way to achieve sustainable development in rural areas? Smart village planning and practices in China. Sustainability, 12(24), 105 